\title{
PENGARUH BUDAYA ORGANISASI DAN KOHESIVITAS KELOMPOK TERHADAP KEPUASAN KERJA KARYAWAN DI PT BANK BNI SYARIAH
}

\author{
THE INFLUENCE OF ORGANIZATIONAL CULTURE AND GROUP COHESIVENESS ON JOB \\ SATISFACTION OF EMPLOYEES AT PT BANK BNI SYARIAH
}

\author{
Fitri Fajriyanti")1, Nurmala K Panjaitan**), dan Sadikin Kuswanto*) \\ *) Sekolah Bisnis, IPB University \\ Jl. Pajajaran, Bogor, Indonesia 16151 \\ **) Departemen Sains Komunikasi dan Pengembangan Masyarakat, Fakultas Ekologi Manusia, IPB University \\ Jl. Dramaga, Kampus Darmaga Bogor 16680
}

\begin{abstract}
PT Bank BNI Syariah, in achieving its targets and the company goals, it required qualified human resources (HR), which were capable of synergizing among fellow employees. This study was analyzing the influence of organizational culture and group cohesiveness on employee job satisfaction. A quantitative approach and purposive sampling technique was used to interview respondents. The Data were analyzed by Partial Least Square (PLS). The results of PLS analysis showed that applying organizational culture and increasing group cohesiveness could increase job satisfaction. Organizational culture had a significant positive effect on job satisfaction. In this case, organizational culture played an important role in increasing job satisfaction. Since employees who were able to understand and apply organizational culture in a good manner will deliver job satisfaction. Organizational cultural value guided employees to behave so that its application influenced employee behavior that leads to the creation of job satisfaction. Group cohesiveness had a significant positive effect on job satisfaction. It affected employee job satisfaction; the higher group cohesiveness gave better job satisfaction. Moreover, organizational culture also had a significant positive influence on group cohesiveness.
\end{abstract}

Keywords: cohesiveness, job satisfaction, organizational culture, PLS, Sharia Commercial Banks

\begin{abstract}
Abstrak: PT Bank BNI Syariah dalam mencapai targetnya sendiri dan tujuan perusahaan, diperlukan sumber daya manusia (SDM) yang berkualitas yang mampu bersinergi di antara sesama karyawan. Penelitian ini bertujuan menganalisis pengaruh budaya organisasi dan kekompakan kelompok terhadap kepuasan kerja karyawan. Menggunakan pendekatan kuantitatif dan menggunakan teknik purposive sampling untuk memilih responden. Data dianalisis dengan bantuan Partial Least Square (PLS). Hasil analisis PLS menunjukkan bahwa menerapkan budaya organisasi dan meningkatkan keterpaduan kelompok dapat meningkatkan kepuasan kerja. Budaya organisasi berpengaruh positif signifikan terhadap kepuasan kerja. Dalam hal ini, budaya organisasi memainkan peran penting dalam meningkatkan kepuasan kerja karena karyawan yang mampu memahami dan menerapkan budaya organisasi dengan baik akan memberikan kepuasan kerja. Nilai budaya organisasi memandu karyawan dalam berperilaku, sehingga penerapannya akan memengaruhi perilaku karyawan yang mengarah pada terciptanya kepuasan kerja. Keterpaduan kelompok memiliki pengaruh positif signifikan terhadap kepuasan kerja. Ini akan mempengaruhi kepuasan kerja karyawan; semakin tinggi keterpaduan kelompok, semakin baik kepuasan kerja karyawan. Selain itu, budaya organisasi juga memiliki pengaruh positif yang signifikan terhadap kekompakan kelompok.
\end{abstract}

Kata kunci: kohesivitas, kepuasan kerja, budaya organisasi, PLS, Bank Umum Syariah

\footnotetext{
${ }^{1}$ Alamat Korespondensi:

Email: fitri.fajriyanti@gmail.com
} 


\section{PENDAHULUAN}

Pertumbuhan perusahaan-perusahaan di Indonesia akhir-akhir ini berkembang begitu pesat, melihat dari bertambahnya perusahaan termasuk pada industri perbankan. Persaingan pada industri perbankan semakin dirasakan, termasuk pada industri perbankan syariah. Berdasarkan data OJK (2018) saat ini jumlah Bank Umum Syariah (BUS) mencapai 13 bank dan jumlah Bank Umum Konvensional yang memilliki Unit Usaha Syariah (UUS), yaitu 21 bank. Angka tersebut meningkat dari sebelumnya pada tahun 2009 jumlah BUS hanya berjumlah enam bank, sedangkan UUS berjumlah 25 bank (OJK, 2017). Adanya perkembangan dari UUS menjadi BUS menunjukkan bahwa saat ini industri perbankan syariah sudah semakin berkembang, sehingga beberapa Bank Umum Konvensional yang memiliki UUS kini semakin bersaing dan mengembangkan unit syariahnya menjadi BUS. Perkembangan pada industri perbankan syariah juga didukung dengan adanya peningkatan kinerja BUS dan UUS pada tahun 2017 yang tercermin dari kenaikan total aset, pembiayaan, dan dana pihak ketiga (DPK) masing-masing sebesar 18,98\% (yoy), 15,20\% (yoy) dan 19,83\% (уоу) (OJK, 2017).

PT Bank BNI Syariah merupakan tiga besar dari Bank Umum Syariah (BUS) yang memiliki kantor cabang terbanyak dengan jumlah 68 kantor cabang (OJK, 2018). Semakin ketatnya persaingan di industri perbankan mengharuskan PT. Bank BNI Syariah untuk manjadi bank yang memiliki keunggulan agar dapat bersaing di industri perbankan. Hal ini juga sejalan dengan visi PT Bank BNI Syariah yaitu "menjadi bank syariah yang unggul dalam layanan dan kinerja". Salah satu upaya yang dapat dilakukan PT Bank BNI Syariah dalam meningkatkan keunggulan adalah dengan mempersiapkan sumber daya manusia (SDM) yang berkualitas. Berbagai upaya dalam peningkatan kualitas SDM dapat dilakukan, salah satunya dengan memperhatikan kepuasan kerja karyawan.

Pada saat ini sering kali terjadi bahwa karyawan merasa belum tercukupi dengan mendapatkan imbalan dari pekerjaan saja, sehingga karyawan juga ingin mendapatkan kepuasan dari pekerjaannya. Kepuasan merupakan evaluasi yang menggambarkan seseorang atas perasaan sikapnya senang atau tidak puas dalam bekerja (Rivai, 2004). Kepuasan kerja dapat memberikan rasa semangat karyawan dalam bekerja serta loyalitas karyawan. Karyawan dengan tingkat kepuasan kerja tinggi mempunyai perasaan positif tentang pekerjaan mereka. Karyawan yang merasa puas dengan pekerjaannya maka akan merasa semangat dalam bekerja sehingga kinerjanya pun akan meningkat. Sebaliknya, karyawan yang merasa tidak puas dengan pekerjaannya akan cenderung memberikan kontribusi yang tidak maksimal untuk perusahaan sehingga kinerjanya menurun. Berbagai cara dapat dilakukan perusahaan dalam mewujudkan kepuasan kerja karyawan, diantaranya melalui budaya organisasi dan kohesivitas kelompok.

Budaya organisasi disebut juga budaya perusahaan. Menurut Masrukhin dan Waridin (2006) budaya organisasi merupakan suatu sistem nilai yang diperoleh dan dikembangkan oleh organisasi dan pola kebiasaan dan falsafah dasar pendirinya. Budaya organisasi terbentuk menjadi aturan yang digunakan sebagai pedoman dalam berfikir dan bertindak dalam mencapai tujuan organisasi. Individu-individu di organisasi yang memiliki latar belakang berbeda atau berada pada tingkatan yang tidak sama dalam organisasi diharapkan dapat memahami budaya organisasi dengan pengertian yang serupa (Chasanah, 2008). Hasil penelitian pada karyawan BUMN, yaitu PT Jamsostek menunjukkan budaya organisasi mempunyai pengaruh positif dan signifikan terhadap kepuasan kerja (Ritawati, 2013). Budaya organisasi bahkan juga mempengaruhi kepuasan kerja berdasarkan hasil penelitian Taurisa dan Ratnawati (2012) pada karyawan manufaktur PT. Sido Muncul Kaligawe Semarang. Lebih lanjut, menurut hasil penelitian Kusumawati (2008) pada karyawan RS Roemani Semarang juga menunjukkan bahwa budaya organisasi secara positif dan signifikan berpengaruh terhadap kepuasan kerja karena semakin banyak aspek yang sesuai pada diri individu yang dapat berpengaruh pada kepuasan kerja. Penelitian-penelitian yang telah dilakukan menunjukkan adanya pengaruh signifikan budaya organisasi pada kepuasaan kerja karyawan. Kesamaan antara nilai yang tercermin dari budaya organisasi dengan perilaku yang diterapkan karyawan akan menciptakan perasaan puas pada karyawan. PT Bank BNI Syariah memiliki nilai-nilai budaya organisasi yang tercermin dalam budaya kerja Amanah dan Jamaah. Berdasarkan isu-isu yang telah dipaparkan, penelitian ini memiliki kesamaan variabel terikat dan variabel bebas yang diteliti sehingga hasil penelitian ini dapat mendukung temuan yang sudah ada sebelumnya. Namun begitu, penelitian ini memiliki perbedaan dari segi obyek penelitian, alat analisis dan indikator-indikator yang digunakan untuk 
mengukur setiap variabel. Indikator dari variabel budaya organisasi didasarkan pada nilai budaya kerja PT Bank BNI Syariah yang dikenal dengan Amanah dan Jamaah yang terdiri dari sepuluh perilaku budaya kerja yaitu diantaranya jujur dan menepati janji, bertanggung jawab, bersemangat untuk menghasilkan karya terbaik, bekerja ikhlas dan mengutamakan niat ibadah, melayani melebihi harapan, peduli dan berani memberi umpan balik yang konstruktif, membangun sinergi secara profesional, sebarluaskan ilmu yang bermanfaat, memahami keterkaitan proses kerja, memperkuat kepemimpinan yang efektif. Sepuluh dimensi tersebut diharapkan dapat mengetahui gambaran penerapan budaya organisasi di PT Bank BNI Syariah KC Jakarta Timur. Selanjutnya variabel kohesivitas kelompok diukur berdasarkan pada dimensi kohesivitas yang dikemukakan oleh Carron et al. (2009), yakni group integration-task (GIT), group integrationsocial (GIS), individual attractions to the group-task (ATGT), dan individual attraction to the group-social (ATGS). Sementara itu, variabel kepuasan kerja diukur berdasarkan lima aspek penting dari kepuasan kerja yang dikembangkan oleh Colquitt et al. (2013), yakni kepuasan pembayaran, kepuasan promosi, kepuasan supervisi, kepuasan rekan kerja, dan kepuasan terhadap pekerjaan.

Upaya manajemen Bank Syariah dalam bersaing di industri perbankan serta mewujudkan visi perusahaan untuk menjadi bank syariah yang unggul, selain melalui peranan budaya organisasi juga diperlukan kerjasama sesama karyawan dan tindakan saling mendukung satu sama lain. Melalui sikap saling sinergi sesama karyawan akan lebih mudah bagi perusahaan dalam mencapai tujuan organisasi. Menurut Putrianti (2012) bahwa perasaan kebersamaan dan rasa kerjasama dalam melaksanakan tugas merupakan bagian dari kohevisitas kelompok kerja. Kohevisitas kelompok kerja merupakan sejauh mana anggota kelompok tertarik satu sama lain antar anggota kelompok dan termotivasi untuk berada dalam kelompok tersebut. Kelompok kerja dengan kohesivitas kelompok yang tinggi memiliki keinginan yang lebih besar untuk bekerja sama dalam mencapai tujuan kelompok, serta memiliki komitmen yang tinggi untuk mempertahankan kelompoknya tersebut. Oleh karena itu, kohesivitas penting karena akan memengaruhi produktivitas kelompok sebab dalam kohesivitas kelompok juga adanya tindakan saling mendukung. Lingkungan kerja dan organisasi yang mampu menciptakan rasa nyaman dan saling mendukung dapat ditingkatkan melalui budaya organisasi. Budaya organisasi akan menjadi pedoman bagi seluruh lapisan individu yang ada di dalam organisasi tersebut dalam menjalankan tugasnya, sehingga nilai-nilai dalam budaya organisasi yang diterapkan oleh karyawan akan berpengaruh terhadap kohesivitas kelompok. Apabila budaya dalam organisasi tersebut kuat maka kekohesifan kelompok semakin kuat.

PT. Bank BNI Syariah KC Jakarta Timur merupakan salah satu kantor cabang PT. Bank BNI Syariah kelas satu (champion) di Wilayah Jabodetabek Plus (WJP). Keberhasilan PT. Bank BNI Syariah KC Jakarta Timur dalam pencapaian tujuan perusahaan membutuhkan SDM yang berkualitas dan mampu bersinergi antara sesama karyawan untuk mencapai tujuan perusahaan. Salah satu upaya yang dilakukan manajemen untuk mendukung hal tersebut, yaitu dengan memberikan perhatian terhadap kesejahteraan dan perkembangan SDM nya, dengan kata lain perusahaan dapat memberikan kepuasan terhadap karyawannya. PT. Bank BNI Syariah memiliki budaya organisasi yang dituangkan dalam sepuluh nilai budaya kerja Amanah dan Jamaah. Diharapkan budaya organisasi tersebut dapat diterapkan dan menjadi panutan karyawan dalam berperilaku, yang nantinya akan meningkatkan kohesivitas kelompok serta kepuasan kerja karyawan.

Manajemen dituntut untuk memahami hal-hal yang berpengaruh terhadap kepuasan kerja karyawan. Karyawan yang merasa puas terhadap kerjanya akan memberikan kontribusi maksimal terhadap perusahaan, sehingga hal tersebut dapat meningkatkan kinerja perusahaan. Berdasarkan paparan tersebut, terciptanya kepuasan kerja karyawan diduga dapat dibangun melalui penerapan budaya organisasi dan meningkatkan kohesivitas kelompok. Apabila karyawan merasa puas maka karyawan tersebut akan lebih semangat dalam bekerja sehingga tercipta loyalitas dan peningkatan prestasi kerjanya. Oleh sebab itu, penulis tertarik untuk melakukan penelitian mengenai pengaruh budaya organisasi dan kohesivitas kelompok terhadap kepuasan kerja karyawan di PT Bank BNI Syariah KC Jakarta Timur. Tujuan penelitian ini untuk menganalisis pengaruh budaya organisasi dan kohesivitas kelompok terhadap kepuasan kerja karyawan di PT Bank BNI Syariah KC Jakarta Timur. 


\section{METODE PENELITIAN}

Penelitian ini dilaksanakan pada bulan Juli - September 2018 yang dilakukan di PT. Bank BNI Syariah Kantor Cabang (KC) Jakarta Timur beserta kantor cabang pembantu (KCPS) dan kantor kas (KK). Kantor cabang Jakarta Timurmembawahilimakantor cabang pembantu di Kalimalang, Cibubur, Dewi Sartika, Buaran, dan Otista, serta satu kantor kas di Lubang Buaya. Data yang diperlukan dalam penelitian ini adalah data primer dari kuesioner yang diberikan kepada responden secara face to face, dan data sekunder diperoleh dari bukubuku teks ilmiah mengenai SDM, hasil penelitian terdahulu seperti jurnal, tesis, dan disertasi, data dari OJK, serta data perusahaan.

Unit analisis dalam penelitian ini adalah karyawan (banking staff) PT. Bank BNI Syariah KC Jakarta Timur (kecuali satpam, cleaning service, dan supir). Responden dibatasi dengan kriteria masa kerja sekurang-kurangnya enam bulan, hal ini dengan asumsi bahwa karyawan yang telah melewati masa kerja enam bulan dinilai sudah mempunyai sikap terhadap lingkungan kerjanya. Jumlah responden yang memenuhi kriteria berjumlah 87 orang. Pada penelitian ini, teknik pengambilan sampel dilakukan berdasarkan metode non-probability sampling yaitu secara purposive sampling yang dilakukan berdasarkan penentuan kriteria responden. Responden diwawancara langsung dengan kuesioner yang terstruktur. Penelitian ini dilakukan pada saat setelah jam kerja untuk karyawan di unit layanan, kantor cabang pembantu dan kantor kas. Sedangkan karyawan di unit lainnya dilakukan pada saat setelah morning briefing atau pada saat setelah jam istirahat (kondisional).

Pada penelitian ini terdapat tiga variabel yang akan diamati, yaitu budaya organisasi, kohesivitas kelompok, dan kepuasan kerja. Variabel laten eksogen adalah budaya organisasi, sedangkan variabel laten endogen yaitu kohesivitas kelompok dan kepuasan kerja. Setiap variabel diukur dengan menggunakan kuesioner. Setiap pernyataan diukur dengan skala Likert mulai dari "sangat tidak setuju" (1) sampai ke "sangat setuju" (5). Penelitian ini menggunakan analisis kuantitatif, sikap responden merupakan data kualitatif yang akan diukur dengan suatu skala sehingga hasilnya berbentuk angka yang selanjutnya angka atau skor tersebut diolah dengan metode statistik. Untuk menganalisis data kuantitatif dalam penelitian ini menggunakan teknik analisis data SEM Partial Least Square (PLS).
Visi PT Bank BNI Syariah, yaitu menjadi bank syariah yang unggul dalam layanan dan kinerja. Untuk mewujudkan visi tersebut dikala semakin ketatnya persaingan di industri perbankan maka PT Bank BNI Syariah perlu dukungan dari SDM yang berkualitas. Upaya peningkatan kualitas SDM dapat dilakukan dengan memperhatikan kepuasan kerja karyawan diantaranya melalui peranan budaya organisasi serta sikap saling mendukung sesama karyawan agar tercipta kerja sama kelompok yang saling bersinergi dalam mencapai tujuan perusahaan.

Berdasarkan teori serta hasil penelitian terdahulu bahwa kepuasan kerja karyawan dapat dipengaruhi oleh beberapa faktor, diantaranya melalui budaya organisasi dan kohesivitas kelompok. Dengan demikian, diharapkan dengan nilai budaya kerja PT Bank BNI Syariah Amanah dan Jamaah sebagai budaya organisasi yang dianut dapat diserap dengan baik oleh karyawan, sehingga karyawan dapat menganut budaya organisasi tersebut sebagai bagian dari budaya kerja dirinya, yang pada akhirnya dapat meningkatkan kohesivitas kelompok serta kepuasan kerja karyawan.

Budaya organisasi dan kepuasan kerja

Menurut Novita (2016) budaya organisasi dapat memengaruhi perilaku karyawan dalam bekerja, yang semakin lama akan membenuk kebiasaan. Budaya yang kuat artinya seluruh karyawan memiliki satu shared meaning yang sama dalam mencapai tujuan perusahaan. Beberapa penelitian terdahulu menunjukkan adanya pengaruh budaya organisasi terhadap kepuasan kerja. Hasil penelitian Kusumawati (2008) menunjukkan bahwa budaya organisasi secara positif dan signifikan berpengaruh terhadap kepuasan kerja. Semakin banyak aspek-aspek yang terdapat pada diri individu yang sesuai dengan budaya organisasi tempatnya bekerja maka akan semakin tinggi kepuasan kerjanya. Adanya hubungan budaya organisasi dengan kepuasan kerja juga didukung oleh hasil penelitian Zahra (2013) bahwa budaya organisasi memberikan pengaruh terhadap kepuasan kerja. H1: Budaya organisasi berpengaruh terhadap kepuasan kerja

Kohesivitas kelompok dan kepuasan kerja

Kohesivitas kelompok berhubungan dengan kepuasan kerja.MenurutKrisnasaridanPurnomo(2017)kelompok yang memiliki kohesivitas tinggi akan berusaha untuk menjadi satu dalam kelompok dengan bekerja bersama- 
sama dalam mencapai tujuan kelompok. Adanya rekan kerja yang mendukung dapat memengaruhi kepuasan kerja karyawan. Hal ini didukung oleh penelitian Larasati et al. (2017) yang menyebutkan bahwa kohesivitas berpengaruh langsung positif terhadap kepuasan kerja. Semakin erat kohesivitas yang dimiliki karyawan maka semakin tinggi pula kepuasan kerja yang dirasakan karyawan. H2: Kohesivitas kelompok berpengaruh terhadap kepuasan kerja

\section{Budaya organisasi dan kohesivitas kelompok}

Menurut pandangan PT Bank BNI Syariah, budaya kerja merupakan nilai-nilai dan keyakinan yang menjadi pedoman dalam berperilaku, yang dinilai penting bagi kelangsungan suatu organisasi. Robbins dan Judge (2015) menyebutkan bahwa dalam suatu budaya yang kuat, nilai-nilai organisasi akan dianut secara intensif dan disebarkan secara luas. Semakin banyak anggota organisasi yang menerima nilai organisasi dan semakin besar komitmen mereka, maka akan semakin kuat budaya dan semakin besar pengaruhnya terhadap perilaku anggota organisasi. Budaya organisasi yang kuat akan mampu mempengaruhi perilaku anggotanya, sehingga perilaku anggota organisasi dapat dibangun darinilai-nilaibudaya organisasi. Pada nilaibudaya kerja PT Bank BNI Syariah, mengandung nilai budaya yang dapat membangun kohesivitas. H3: udaya organisasi berpengaruh terhadap kohesivitas kelompok
Berdasarkan teori serta hasil penelitian terdahulu bahwa kepuasan kerja karyawan dapat dipengaruhi oleh beberapa faktor, diantaranya melalui budaya organisasi dan kohesivitas kelompok. Dengan demikian, diharapkan dengan nilai budaya kerja PT Bank BNI Syariah Amanah dan Jamaah sebagai budaya organisasi yang dianut dapat diserap dengan baik oleh karyawan, sehingga karyawan dapat menganut budaya organisasi tersebut sebagai bagian dari budaya kerja dirinya, yang pada akhirnya dapat meningkatkan kohesivitas kelompok serta kepuasan kerja karyawan. Kerangka pikir konseptual pada penelitian ini disajikan dalam bentuk bagan seperti pada Gambar 1 .

\section{HASIL}

\section{Karakteristik Responden}

Karakteristik responden yang digunakan dalam penelitian ini terbagi menjadi beberapa kriteria seperti yang disajikan pada Tabel 1. Respondenyang merupakan karyawan PT Bank BNI Syariah KC Jakarta Timur mayoritas berada pada usia produktif pada rentang usia 20-30 tahun. Mayoritas responden berjenis kelamin perempuan. Responden dengan status menikah lebih mendominasi dibandingkan responden dengan satstus belum menikah. Responden dengan jabatan sebagai assistant juga lebih mendominasi dibanding dengan jabatan lainnya. Mayoritas responden memiliki masa kerja $<1-5$ tahun, tingkat pendidikan responden lebih didominasi oleh jenjang Sarjana (S1).

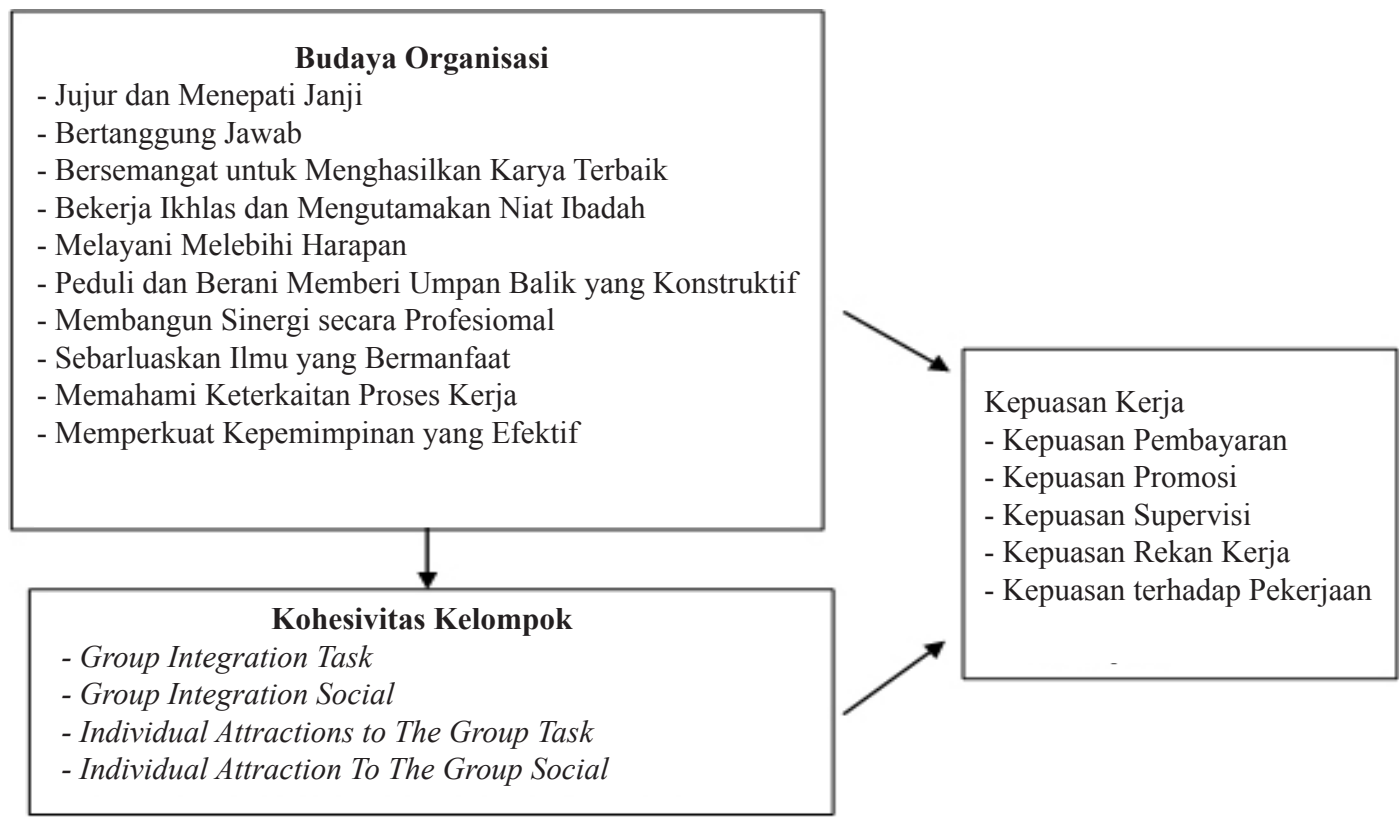

Gambar 1 Kerangka pemikiran penelitian 
Tabel 1. Karakteristik responden

\begin{tabular}{llc}
\hline Karakteristik Responden & Persentase (\%) \\
\hline Usia & 20-30 tahun & 79 \\
& $31-40$ tahun & 16 \\
& $>40$ tahun & 5 \\
Jenis Kelamin & Laki-laki & 41 \\
& Perempuan & 59 \\
Status Pernikahan & Belum Menikah & 44 \\
& Menikah & 56 \\
Jabatan & Assistant & 67 \\
& Officer & 11 \\
& Supervisor & 11 \\
& Junior Manager & 10 \\
Masa Kerja & $<1-5$ tahun & 67 \\
& 6-10 tahun & 23 \\
Pendidikan & $>10$ tahun & 10 \\
& SMA & 7 \\
& Diploma & 17 \\
& Sarjana (S1) & 76 \\
\hline \multirow{5}{*}{ Sal } & &
\end{tabular}

\section{Hasil Uji Stuctural Equation Model - Partial Least Square (SEM-PLS)}

Alat analisis yang digunakan untuk mengetahui hubungan antara variabel pada penelitian adalah Partial Least Square dengan menggunakan software Smart PLS versi 3.0. Dalam menganalisis hubungan antara variabel laten serta menganalisis indikator yang memengaruhi variabel laten, maka disusun suatu model persamaan struktural. Variabel laten dalam penelitian ini terdiri dari variabel budaya organisasi, kohesivitas kelompok dan kepuasan kerja. Variabel laten eksogen adalah budaya organisasi, sedangkan variabel laten endogen yaitu kohesivitas kelompok dan kepuasan kerja. Model yang dibangun merupakan bentuk struktural dari hubungan antara variabel indikator dengan variabel laten eksogen dan endogen. Dalam menilai kriteria kesesuaian model (goodness of fit) dibagi dua, yaitu outer model (model pengukuran) dan inner model (model struktural).

\section{Uji Kecocokan Model Pengukuran (Evaluasi Outer Model)}

Outer model merupakan model pengukuran untuk menilai validitas dan reliabilitas model. Pengujian validitas konvergen dari model pengukuran dinilai berdasarkan nilai faktor muatan (loading factor) dari masing-masing konstruk. Penelitian ini menggunakan batas loading factor sebesar 0,50 sehingga validitas konvergen akan terpenuhi jika nilai loading factor
$>0,5$ (Ghozali, 2012). Pada Gambar 2, nilai loading factor pada masing-masing variabel dalam penelitian memiliki nilai $>0,50$. Hal ini menunjukkan bahwa atribut variabel memiliki tingkat validitas yang tinggi, sehingga validitas konvergen sudah terpenuhi.

Pengujian reliabilitas konstruk dilakukan setelah uji validitas telah terpenuhi. Pengujian reliabilitas konstruk atau variabel laten dapat diukur dengan melihat nilai composite reliability dari blok indikator yang mengukur konstruk. Konstruk dinyatakan reliabel jika nilai composite reliabilty $>0,70$. Pada Tabel 2 dapat dilihat bahwa nilai hasil pengujian composite reliability (CR) menunjukkan bahwa nilai untuk semua konstruk $>0,70$. Dengan demikian bahwa semua konstruk memiliki reliabilitas yang baik sesuai dengan batas minimum yang disyaratkan sehingga indikatorindikator yang digunakan benar-benar dapat dipercaya untuk mengukur konstruknya.

\section{Uji Kecocokan Model Struktural (Evaluasi Inner Model)}

Berdasarkan hasil pengujian diperoleh nilai koefisien determinasi (R2) sebesar 0,577 yang artinya sebanyak $57,7 \%$ kepuasan dipengaruhi oleh budaya organisasi dan kohesivitas kelompok karyawan PT Bank BNI Syariah KC Jakarta Timur, sedangkan sisanya dipengaruhi oleh faktor lain. Pernyataan mengenai adanya pengaruh budaya organisasi terhadap kepuasan kerja didukung oleh hasil penelitian Chasanah (2008), serta Taurisa dan ratnawati (2012), bahwa budaya organisasi memberikan pengaruh terhadap kepuasan kerja. Variabel budaya organisasi dan kohesivitas hanya memberikan sumbangan yang sedang dalam memengaruhi kepuasan kerja karyawan di PT Bank BNI Syariah KC Jakarta Timur. Menurut Vidianingtyas dan Putri (2014) bahwa kepuasan kerja dipengaruhi oleh faktor instrinsik dan ekstrinsik. Faktor instrinsik meliputi kecerdasan, kecakapan khusus, umur, jenis kelamin, kondisi fisik, pendidikan, pengalaman kerja, masa kerja, kepribadian, emosi, cara berpikir, persepsi dan sikap kerja. Sedangkan faktor ekstrinsik meliputi jenis pekerjaan, struktur organisasi, jabatan, jaminan financial, kesempatan promosi jabatan, interaksi sosial dan hubungan kerja. Faktor lain yang mempengaruhi kepuasan kerja berdasarkan penelitian terdahulu yakni dari hasil penelitian Jabar et al. (2014) dan Suprapta et al. (2015) bahwa kepemimpinan berpengaruh nyata terhadap kepuasan kerja. 


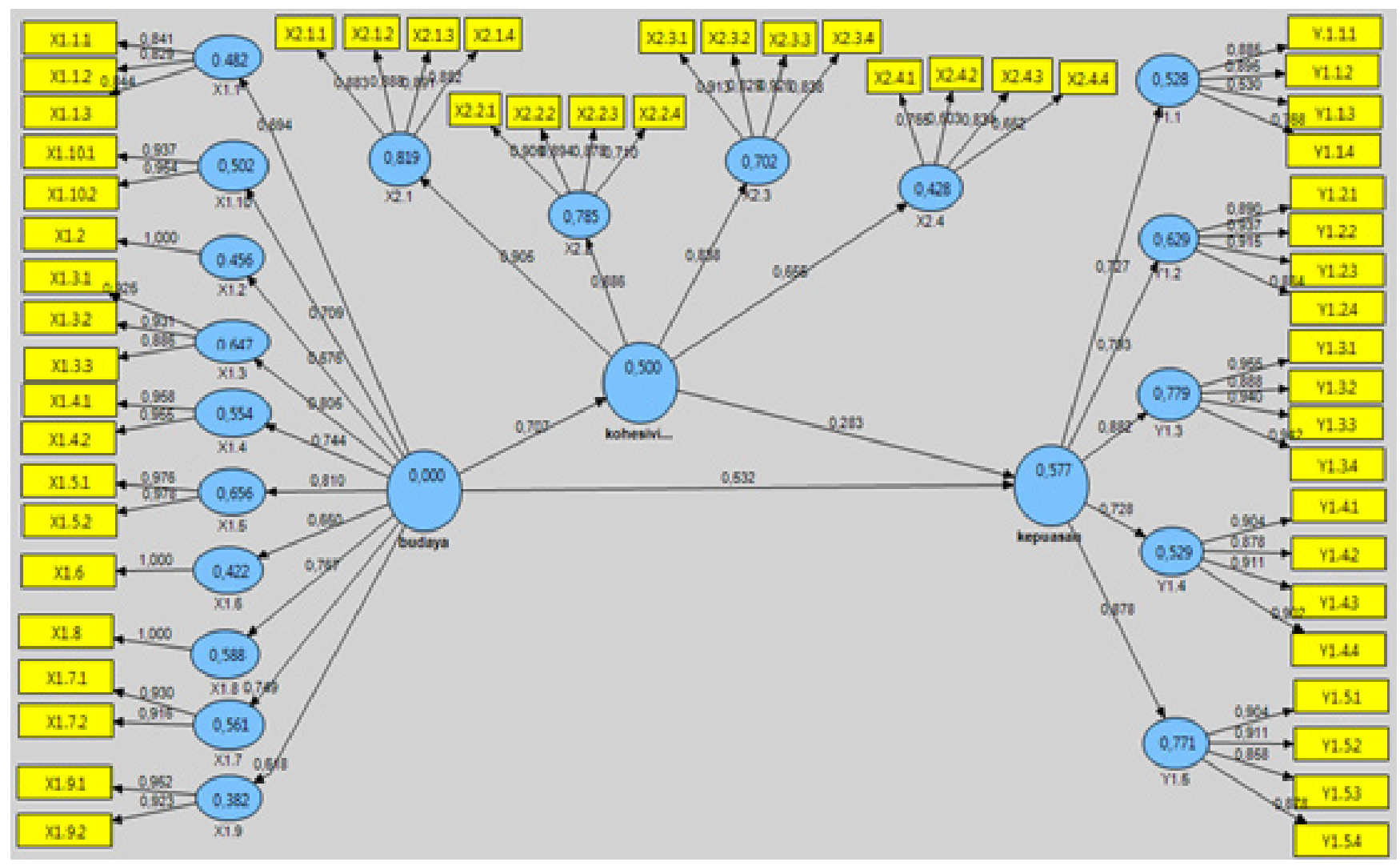

Gambar 2 Standardized loading factor hasil analisis PLS

Tabel 2, Nilai composite reliabilty

\begin{tabular}{lc}
\hline Variabel/Dimensi & Composite Reliability \\
\hline X1,1 & 0,876286 \\
X1.2 & 1,000000 \\
X1.3 & 0,938759 \\
X1.4 & 0,955548 \\
X1.5 & 0,976781 \\
X1.6 & 1,000000 \\
X1.7 & 0,919669 \\
X1.8 & 1,000000 \\
X1.9 & 0,935801 \\
X1.10 & 0,944361 \\
X2.1 & 0,935921 \\
X2.2 & 0,912859 \\
X2.3 & 0,930234 \\
X2.4 & 0,788224 \\
Y1.1 & 0,859956 \\
Y1.2 & 0,948759 \\
Y1.3 & 0,963328 \\
Y1.4 & 0,943980 \\
Y1.5 & 0,937180 \\
\hline Budaya Organisasi & 0,942561 \\
Kohesivitas Kelompok & 0,942488 \\
Kepuasan Kerja & 0,954376 \\
\hline
\end{tabular}

Pengaruhvariabelbudayaorganisasiterhadapkohesivitas memiliki nilai R2 sebesar 0,500 yang artinya bahwa $50 \%$ kohesivitas dipengaruhi oleh budaya organisasi, sedangkan sisanya dipengaruhi oleh faktor yang lain. Budaya organisasi tidak sepenuhnya memberikan pengaruh terhadap kohesivitas. Menurut Mullins (2005) kekohesifan sebuah kelompok dipengaruhi oleh empat dimensi, yakni keanggotaannya, lingkungan kerja, organisasi, serta perkembangan dan kematangan anggota kelompoknya. Sementara Iskandar dan Syueb (2017) menemukan bahwa terdapat hubungan yang signifikan antara komunikasi yang efektif dengan kohesivitas kelompok.

Pada pengujian kecocokan model struktural (inner model) selain melihat nilai koefisien determinasi (R2), juga melihat nilai koefisien jalur. Menurut Lehner dan Haas (2010), nilai koefisien jalur ( $\beta$ ) yang berada dalam rentang nilai $-0,1$ hingga 0,1 dianggap tidak signifikan, nilai yang lebih besar dari 0,1 merupakan nilai yang signifikan dan berbanding lurus. Nilai koefisien jalur dapat dilihat pada Gambar 1, seluruh jalur memiliki nilai koefisen lebih besar dari 0,1 artinya semua jalur mempunyai nilai yang signifikan. 
Variabel budaya organisasi memiliki sepuluh dimensi yaitu jujur dan menepati janji (X1.1), bertanggung jawab (X1.2), bersemangat untuk menghasilkan karya terbaik (X1.3), bekerja ikhlas dan mengutamakan niat ibadah (X1.4), melayani melebihi harapan (X1.5), peduli dan berani memberi umpan balik yang konstruktif (X1.6), membangun sinergi secara profesional (X1.7), sebarluaskan ilmu yang bermanfaat (X1.8), memahami keterkaitan proses kerja (X1.9), memperkuat kepemimpinan yang efektif (X1.10). Dilihat dari nilai koefisien jalur, dimensi melayani melebihi harapan memiliki nilai koefisien jalur yang paling tinggi yakni sebesar 0,810053. Hal ini berarti bahwa karyawan yang bekerja dengan memberikan layanan sepenuh hati (service excellent) kepada customer serta bekerja dengan tulus, memberikan pengaruh terbesar dalam membentuk budaya organisasi pada PT Bank BNI Syariah KC Jakarta Timur.

Variabel kohesivitas terbentuk oleh empat dimensi, yaitu group integration task - GIT (X2.1), group integration social - GIS (X2.2), individual attractions to the group task - ATGT (X2.3), dan individual attraction to the group social - ATGS (X2.4). Dilihat dari nilai koefisien jalur, pembentuk variabel kohesivitas kelompok yang tertinggi adalah group integration task (GIT) sebesar 0,904831 artinya bahwa persepsi yang masingmasing anggota yakini tentang tim dalam aspek tugas memberikan pengaruh terbesar dalam membentuk variabel kohesivitas kelompok. Kohesivitas karyawan di PT Bank BNI Syariah KC Jakarta Timur lebih banyak dibentuk dari adanya kekompakan dalam tim, tanggung jawab dan juga komitmen anggota tim yang meliputi aspek tugas.

Variabel kepuasan kerja memiliki lima dimensi yaitu kepuasan pembayaran (Y1.1), kepuasan promosi (Y1.2), kepuasan supervisi (Y1.3), kepuasan rekan kerja (Y1.4), dan kepuasan pekerjaan (Y1.5). Dilihat dari nilai koefisien jalur, pembentuk variabel kepuasan kerja tertinggi adalah kepuasan supervisi sebesar 0,882332 . Hal ini berarti bahwa perasaan kayawan terhadap atasan mereka dapat memberikan pengaruh yang besar dalam membentuk variabel kepuasan kerja karyawan PT Bank BNI Syariah KC Jakarta Timur. Pemberian bimbingan, bantuan serta motivasi dari atasan memberikan pengaruh yang paling besar terhadap kepuasan kerja karyawan di PT Bank BNI Syariah KC Jakarta Timur.

\section{Pengujian Hipotesis}

Pengambilan keputusan pada pengujian hipotesis ini (Tabel 3) adalah menerima hipotesis jika nilai t hitung lebih besar dari nilai t-tabel dengan taraf signifikansi $(\alpha)$ $5 \%$, yaitu sebesar 1,987. Pada penelitian ini digunakan uji-t dengan signifikansi $(\alpha)$ 5\% untuk menentukan tingkat signifikansi hubungan antara indikator dengan variabel latennya atau antar variabel laten itu sendiri.

Hubungan Budaya Organisasi tehadap Kepuasan Kerja

Hubungan antara budaya organisasi terhadap kepuasan kerja mempunyai nilai t-statistik sebesar 5,867397. Nilai t-statistik $>1,987$ maka terdapat pengaruh yang signifikan antara budaya organisasi dengan kepuasan kerja dan hipotesis H1 diterima. Nilai koefisien jalur sebesar 0,532209 yang menunjukkan bahwa arah hubungan antara budaya oganisasi dengan kepuasan kerja adalah hubungan yang positif, artinya bahwa meningkatnya penerapan budaya organisasi dapat meningkatkan kepuasan kerja karyawan. Penelitian ini memperkuat hasil penelitian yang telah dilakukan oleh Abadiyah dan Purwanto (2016) serta Tumbelaka et al. (2016) yang menyatakan bahwa budaya organisasi berpengaruh signifikan terhadap kepuasan kerja. Semakin kuat budaya organisasi dalam perusahaan, maka kepuasan kerja karyawan akan semakin meningkat. Kesamaan antara nilai yang tercermin dari budaya organisasi dengan perilaku yang diterapkan karyawan akan menciptakan perasaan puas pada karyawan. Karyawan yang telah memahami budaya organisasi dengan baik akan memberikan kepuasan tersendiri bagi karyawan dalam bekerja sehingga semakin banyak aspek-aspek yang terdapat pada diri karyawan yang sesuai dengan budaya organisasi tempatnya bekerja maka akan semakin tinggi kepuasan kerjanya.

Hubungan Kohesivitas terhadap Kepuasan Kerja

Hubungan antara kohesivitas terhadap kepuasan kerja mempunyai nilai T-statistik sebesar Nilai t-statistik 3,505669 > 1,987 sehingga dapat disimpulkan terdapat pengaruh yang signifikan antara kohesivitas dengan kepuasan kerja dan hipotesis $\mathrm{H} 2$ diterima. Nilai koefisien jalur sebesar 0,283429 yang menunjukkan bahwa arah hubungan antara kohesivitas dengan kepuasan kerja adalah hubungan yang positif, artinya semakin baik kohesivitas kelompok maka semakin meningkatkan 
kepuasan kerja. Hasil penelitian ini mendukung dari hasil penelitian Urien et al. (2017) yang menyatakan bahwa baik kohesi tugas maupun kelompok memiliki hubungan positifyang kuat dengan kepuasan kerja. Hasil penelitian juga didukung dari hasil penelitian Bartkus et al. (1997) bahwa kohesivitas memengaruhi kepuasan kerja, dimana Bartkus et al. (1997) menyatakan bahwa tingkat kohesivitas kelompok yang semakin tinggi akan meningkatkan kepuasan kerja.

\section{Hubungan Budaya Organisasi terhadap Kohesivitas}

Hubungan antara budaya organisasi terhadap kohesivitas mempunyai nilai T-statistik sebesar 15,187899. Nilai t-statistik $>1,987$ sehingga dapat disimpulkan terdapat pengaruh yang signifikan antara budaya organisasi dengan kohesivitas dan Hipotesis H3 diterima. Nilai koefisien jalur sebesar 0,706888 yang menunjukkan bahwa arah hubungan antara budaya organisasi dengan kohesivitas adalah hubungan yang positif, artinya bahwa dengan meningkatnya penerapan budaya organisasi maka akan meningkatkan tingkat kohesivitas kelompok dalam suatu organisasi. Budaya organisasi yang kuat akan mampu mempengaruhi perilaku anggota organisasi di dalamnya, dengan demikian semakin banyak nilai budaya organisasi yang mencerminkan sikap kohesivitas yang diterapkan oleh anggota organisai maka dapat meningkatkan kohesivitas kelompok. Kustoro (2010) melakukan pengujian terkait kekohesifan dan budaya kerja. Hasil penelitian menyatakan bahwa terdapat pengaruh positif langsung dan signifikan kekohesifan terhadap budaya kerja, semakin tinggi kekohesifan semakin kuat budaya kerja.

\section{Implikasi Manajerial}

Meningkatkan kepuasan kerja melalui penerapan budaya organisasi pada karyawan yang berkaitan dengan sikap melayani, yaitu memberikan pelayanan sepenuh hati (service excellent) serta bekerja dengan tulus. Sikap melayani tidak hanya diterapkan pada karyawan yang bertugas sebagai frontliner saja, tetapi diterapkan pada segenap karyawan. Untuk meningkatkan sikap melayani pada karyawan dapat dilakukan dengan diberikannya pelatihan mengenai service excellent kepada seluruh karyawan. Sikap melayani juga dinilai penting mengingat bahwa perusahaan bergerak dibidang jasa perbankan. Pada perusahaan jasa, kepercayaan dan pelayanan pada customer merupakan hal utama yang menjadi perhatian. Oleh karena itu, penting bagi perusahaan untuk menjaga kualitas layanannya agar dapat bersaing dengan bank kompetitor lainnya.

Meningkatkan kepuasan kerja melalui peningkatan kohesivitas kelompok yang berkaitan dengan keterpaduan kelompok tugas. Karyawan merasa puas karena mereka menilai bahwa kelompok kerja (tim) mereka memiliki komitmen yang sama untuk keberhasilan kerja tim dan sangat kompak. Untuk meningkatkan keberhasilan kerja dan kekompakan tim, perusahaan perlu mengadakan employee gathering dan team building serta memberikan pelatihan kepada karyawan untuk dapat menghasilkan output kerja yang lebih optimal. Selain itu pemberian reward atau apresiasi bagi tim terbaik atas pencapaian target tim juga akan meningkatkan semangat kerja karyawan untuk saling berlomba memberikan kontribusi yang maksimum. Penyelesaian masalah pekerjaan atau tugas dalam tim mampu meningkatkan kekohesifan dalam tim.

Kepuasan terhadap supervisi memiliki kontribusi tertinggi dalam membentuk kepuasan kerja karyawan di PT Bank BNI Syariah KC Jakarta Timur. Dalam mendapatkan kepuasan terhadap supervisi diperlukan pendekatan interpersonal antara atasan dan karyawan yang mampu memberikan bimbingan, baik dalam hal arahan dan motivasi terkait pekerjaan juga mengenai motivasi kehidupan yang mampu meningkatkan semangat dalam bekerja sesuai niat ibadah. Perusahaan dapat memberikan pelatihan mengenai leadership kepada atasan dan para head atau supervisor agar dapat memahami karyawan dibawahnya. Penelitian ini juga diharapkan dapat menjadi referensi bagi perusahaan sejenis tentang bagaimana menciptakan suasana kerja yang nyaman dan memuaskan bagi karyawan.

Tabel 3. Hasil pengujian hipotesis pada model penelitian

\begin{tabular}{llccc}
\hline Hipotesis & Jalur $($ Path $)$ & Koefisien Jalur & t Statistic & Keterangan \\
\hline H1 & Budaya Organisasi $\rightarrow$ Kepuasan Kerja & 0,532209 & 5,867397 & Signifikan \\
H2 & Kohesivitas $\rightarrow$ Kepuasan Kerja & 0,283429 & 3,505669 & Signifikan \\
H3 & Budaya Organisasi $\rightarrow$ Kohesivitas & 0,706888 & 15,187899 & Signifikan \\
\hline
\end{tabular}

$(\mathrm{db}=\mathrm{n}-1=86$, alpha $=0,05 / 2=0,025, \mathrm{t}$-tabel $=1,98793)$ 


\section{KESIMPULAN DAN SARAN}

\section{Kesimpulan}

Penelitian ini menemukan adanya pengaruh antara budaya organisasi dan kohesivitas kelompok terhadap kepuasan kerja karyawan. Budaya organisasi memiliki pengaruh signifikan positif terhadap kepuasan kerja. Dalam hal ini budaya organisasi berperan penting dalam meningkatkan kepuasan kerja karena karyawan yang mampu menerapkan budaya organisasi dengan baik akan memberikan kepuasan kerja karyawan. Nilai-nilai budaya organisasi menjadi pedoman karyawan dalam berperilaku sehingga penerapan nilai-nilai budaya organisasi akan mempengaruhi perilaku karyawan yang mengarah pada terciptanya kepuasan kerja karyawan. Kohesivitas kelompok memiliki pengaruh signifikan positif terhadap kepuasan kerja. Kekohesifan kelompok akan memengaruhi kepuasan kerja karyawan, semakin tinggi kohesivitas kelompok maka akan meningkatkan kepuasan kerja karyawan.

\section{Saran}

Saran yang dapat dilakukan sehubungan dengan temuan hasil dari penelitian ini, yaitu pada penelitian selanjutnya mengenai budaya organisasi dapat dilakukan dengan mengukur praktek budaya organisasi di perusahaan untuk melihat sejauh mana tingkat penerapan budaya organisasi di perusahaan tersebut. Dalam upaya peningkatan kohesivitas kelompok dan kepuasan kerja karyawan, terdapat faktor lain selain budaya organisasi, sehingga penelitian selanjutnya dapat menambahkan dan menggunakan varaibel lain yang memengaruhi kohesivitas kelompok dan kepuasan kerja seperti gaya kepemimpinan dan komitmen organisasi.

\section{DAFTAR PUSTAKA}

Abadiyah R dan Purwanto D. 2016. Pengaruh budaya organisasi, kompensasi terhadap kepuasan kerja dan kinerja pegawai bank di Surabaya. Jurnal Bisnis, Manajemen dan Perbankan (2)1:49-66. https://doi.org/10.21070/jbmp.v2i1.837.

Bartkus KR, Howell RD, Parent CRM, Hartman CL. 1997. Managerial antecedents and individual consequences of group cohesiveness in travel service selling. Journal of Travel Research 35(4):56-63.https://doi. org/10.1177/004728759703500409.
Carron AV, Eys MA, Lougheed T, Bray SR. 2009. Development of a cohesion questionnaire for youth: the youth sport environment questionnaire. Journal of Sport and Exercise Psychology 31: 390-408.https://doi.org/10.1123/jsep.31.3.390.

Chasanah N. 2008. Analisis pengaruh empowerment, self efficacy dan budaya organisasi terhadap kepuasan kerja dalam meningkatkan kinerja karyawan [tesis]. Semarang: Universitas Diponegoro.

Colquitt JA, Lepine JA, Wesson MJ. 2013. Organizational Behavior: Improving Performance and Commitment in the Workplace. New York: McGraw-Hill.

Ghozali I, Latan H. 2012. Partial Least Square: Konsep, Teknik dan Aplikasi SmartPLS 2.0 M3. Semarang: Universitas Diponegoro Semarang.

Iskandar J, Syueb S. 2017. Pengaruh komunikasi interpersonal dan komunikasi kelompok terhadap kohesivitas kelompok pada supporter persebaya korwil Suramadu. Jurnal Ilmu Komunikasi ULTIMACOMM 9(2): 90-109. https://doi. org/10.31937/ultimacomm.v9i2.812

Jabar I, Isyandi B, Hendriani S. 2014. Pengaruh motivasi dan kepemimpinan terhadap kepuasan kerja dan implikasinya terhadap disiplin kerja tenaga paramedic pada Rumah Sakit Umum Daerah Dr. R. M. Pratomo Kabupaten Rokan Hilir. Jurnal Ekonomi 22(3): 107-122.

Krisnasari ESD, Purnomo JT. 2017. Hubungan kohesivitas dengan kemalasan sosial pada mahasiswa. Jurnal Psikologi 13(1): 13-21. https://doi.org/10.24014/jp.v13i1.2586

Kustoro BD. 2010. Pengaruh kekohesifan, gaya kepemimpinan, dan budaya kerja terhadap efektivitas organisasi. Jurnal Pendidikan dan Kebudayaan 16(3): 325-340. https://doi. org/10.24832/jpnk.v16i3.465.

Kusumawati R. 2008. Analisis pengaruh budaya organisasi dan gaya kepemimpinan terhadap kepuasan kerja untuk meningkatkan kinerja karyawan (studi kasus pada RS Roemani Semarang) [tesis]. Semarang: Universitas Diponegoro.

Larasati RD, Pandjaitan NK, Hermawan A. 2017. Pengaruh kohesivitas dan kepuasan kerja terhadap organizational Citizenship Behavior di PT Agricon. Jurnal Manajemen dan Organisasi 3(2): 157-172. https://doi.org/10.29244/jmo. v8i2.19995 
Lehner F dan Haas N. 2010. Knowledge management success factors - proposal of an empirical research. Electronic Journal of Knowledge Management 8(1):79-90.

Masrukhin dan Waridin. 2006. Pengaruh motivasi kerja, kepuasan kerja, budaya organisasi dan kepemimpinan terhadap kinerja pegawai. Jurnal Ekonomi dan Bisnis (EKOBIS) 7(2): 197-209.

Mullins, LJ. 2005. Management and Organisational Behaviour. New York: Prentice Hall.

Novita F. 2016. Pengaruh gaya kepemimpinan dan budaya organisasi terhadap kinerja karyawan: studi kasus Perusahaan Umum Bulog [tesis]. Bogor: Institut Pertanian Bogor.

[OJK] Otoritas Jasa Keuangan. 2017. Laporan profil industri perbankan triwulan IV 2017. https:// www.ojk.go.id/id/kanal/perbankan/data-danstatistik/laporan-profil-industri-perbankan/ Pages/Laporan-Profil-Industri-Perbankan--Triwulan-IV-2017.aspx [2018 November 2].

[OJK] Otoritas Jasa Keuangan. 2018. Data statistik perbankan syariah 2018.https://www.ojk.go.id/ $\mathrm{id} / \mathrm{kanal} /$ syariah/data-dan-statistik/statistikperbankan-syariah/Pages/Statistik-PerbankanSyariah-Januari-2018.aspx [2018 November 2].

Putrianti FG. 2012. Semangat kerja ditinjau dari kohesivitas kelompok kerja pada mitra pemasaran di KSB Regional V Yogyakarta. Jurnal SPIRITS 3(1): 20-27. https://doi.org/10.30738/spirits. v3i1.1122.

Ritawati A. 2013. Pengaruh kepemimpinan transformasional dan budaya organisasi terhadap kepuasan kerja dan kinerja karyawan PT Jamsostek (Persero) cabang Surabaya. Jurnal Ilmu Ekonomi dan Manajemen 9(1): 82-93.
Rivai V. 2004. Manajemen Sumber Daya Manusia untuk Perusahaan: dari Teori ke Praktek. Jakarta: PT Raja Grafindo Persada.

Robbins SP, Judge TA. 2015. Organizational Behavior 16th Edition. New Jersey: Pearson Education, Inc.

Suprapta M, Sintaasih DK, Riana IG. 2015. Pengaruh kepemimpinan terhadap kepuasan kerja dan kinerja karyawan (studi pada Wake Bali Art Market Kuta-Bali). E-Jurnal Ekonomi dan Bisnis Universitas Udayana 4(6): 430-442.

Taurisa CM, Ratnawati I. 2012. Analisis pengaruh budaya organisasi dan kepuasan kerja terhadap komitmen organisasional dalam meningkatkan kinerja karyawan (studi pada PT. Sido Muncul Kaligawe Semarang). Jurnal Bisnis dan Ekonomi (JBE) 19(2):170-187.https://doi.org/10.24912/ jm.v19i2.129

Tumbelaka SSX, Alhabsji T, Nimran U. 2016. Pengaruh budaya organisasi terhadap kepuasan kerja, komitmen organisasional dan intention to leave (studi pada karyawan PT Bitung Mina Utama). Jurnal Bisnis dan Manajemen 3(1):94-108.

Urien B, Osca A, Salmones LG. 2017. Role ambiguity, group cohesion and job satisfaction: a demandsresources model (JD-R) study from Mexico and Spain .https://doi.org/10.1016/j.rlp.2015.09.014 [2018 November 2].

Vidianingtyas RN, Putri WH. 2014. Pengaruh kompensasi, kepuasan kerja, motivasi kerja, dan gaya kepemimpinan terhadap kinerja karyawan pada perusahaan jasa catering di Daerah Istimewa Yogyakarta. Jurnal Bisnis dan Ekonomi 5(1): 99-110. 